\title{
RECENT DEVELOPMENTS AND CHALLENGES OF THE INTRODUCTION OF DUAL TRAINING FOR SMES IN COUNTRIES AROUND THE BALTIC SEA REGION WITH A SPECIAL EMPHASIS ON LITHUANIA
}

\author{
Max Hogeforster ${ }^{1}$, Christian Wildt ${ }^{2}$ \\ Baltic Sea Academy, Blankeneser Landstrasse 7, 22587 Hamburg, Germany \\ E-mails: ${ }^{1}$ mhogeforster@baltic-sea-academy.eu; ${ }^{2}$ cwildt@baltic-sea-academy.eu (corresponding author)
}

Received 09 April 2020; accepted 07 May 2020

\begin{abstract}
The economy of the Baltic Sea Region is characterised by small and medium-sized enterprises. One of the main limitations to growth continues to be the lack of qualified personnel. Dual training as a form of work-based learning can promote the employability of young people in the long term and attract additional workforce. Based on a review of recent literature the status of VET and dual training in the selected countries of Poland, Latvia, Lithuania and Russia are described. Complementary the first results of a recent survey of companies, schools and administrations is presented, that confirms that in most BSR countries companies are not engaged in dual education. The evaluation of the literature clearly shows that a lot has been done to encourage work-based learning in the Baltic Sea Region, but the survey indicates, that the legal changes and possibilities have yet not fully arrived at the companies that could provide training spots.
\end{abstract}

Keywords: dual education, SMEs, work-based learning, skills-mismatch.

JEL Classification: I21, M20, O36.

\section{Introduction}

Small and medium-sized enterprises (SME) are the driving force for the economy in Europe. The vast majority of these SMEs are micro companies, making up a total of $93 \%$ of all firms and showing the strongest increase in added value (European Commission, 2019). Although young SMEs often have more difficulties to exploit their full potential for innovations due to limited access to finances (Veugelers et al., 2019), there is another very relevant bottleneck for innovation and growth: not enough qualified personnel.

Many companies reported that the lack of qualified employees is a significant barrier for their growth of innovation capacities. Already in 2013 companies in the Baltic Sea Region reported, that the lack of skilled workforce is one of the biggest hindrances to fully develop their business (Hogeforster, 2014). This still holds true and in fact the situation got more challenging today. In particular Lithuania reported the second highest number in the EU member states with $26.5 \%$ of all small companies reporting this challenge, preceded only by Slovenia with $31.2 \%$ (European Commission, 2019). The increasing skill shortage is a very real test for these small companies.

Although the term of skill-mismatch is relatively broad (McGuinness et al., 2017), it is quite clear, that in most countries around the Baltic Sea, the demand of the labour markets does not align with the output of the education system. Even in Sweden, that is showing a rather stable labour market and does not suffer from brain drain like for example Lithuania in recent decades, the skill mismatch can be discussed as the main reason for youth unemployment (Lindberg, 2017). In fact, the reduction of the skill-mismatch will be of consequence for the competitiveness of European SMEs (Nikolov et al., 2018).

A suitable tool to fight the skills-mismatch and to provide the company with trainees and students that already have professional education can be work-based learning (WBL) approaches like a dual education. The dual education system combines the training on the spot, at the company, with the training at the vocational school. This can be interesting to integrate and qualify young people that are weak learners (Priedulena \& Hogeforster, 2017). But it can be also considered a pathway for strong learners and academics. In recent years, the dual education has further developed from apprenticeships to study courses, where "dual students" are trained at the company while studying for example for a bachelor degree at university (Hähn et al., 2016).

Graduates from a dual education are often employed directly from the companies that trained 
them. They are already fully familiar with the company, show increased soft-skills, have the practical know-how, customer-contacts, know their colleagues and do not need any additional training. They are highly valuable for the company from the first day of employment. Current studies confirmed that the importance of soft skills for employability has increased significantly in the last 5-10 years (Succi \& Canovi, 2019). This dual system asks for aligned curricula and a recognition of the skills learned in the company, i.e. for durable partnerships of the stakeholders involved. These partnerships of schools, business intermediaries like chambers and companies can form effective networks to develop and offer the best education for trainees and students (Hogeforster \& Priedulena, 2014).

In the first part, the current state of WBL and vocational education and training (VET) in selected countries around the Baltic Sea is shown on the basis of existing studies and a review of recent literature. In the second part a first evaluation of a current survey is presented.

\section{State of dual education}

One form of WBL, the dual system, has strong traditions in Austria, Netherlands, Switzerland and in particular in Germany (Dessinger, 2000). Also in the northern countries of the Baltic Sea Region, WBL is quite prominent (Michelsen \& Stenström, 2018), although Sweden has reduced the training in companies since 1971 (Lindberg, 2017). In the new member states of the Baltic Sea Region and in Russia there have been more changes in recent years, which justifies to focus on these.

WBL and VET are arranged differently in each Baltic country and consequently analysed from various viewpoints by different researchers. Yet, the ET2020 strategy focuses on all forms of WBL, accompanied by various national policy changes in many Baltic countries. Therefore the legislative framework of WBL has changed fundamentally in numerous Baltic Sea Region countries (Kaikkonen \& Maunonen-Eskelinen, 2020). The analysis of the state of the system, the policy reforms and the challenges differ in each country, as each country realizes its own approaches regarding WBL and VET.

The areas most affected by policy changes are the creation and redesign of curricula, the encouragement of partnerships between VET providers and a shift towards a more practical orientation (Hoftijzer et al., 2018a; Vaitkute et al., 2019; Kiris, 2019; Abankina et al., 2017).
But various challenges remain, especially the training and pay of VET teachers continues to be poor in many countries in the Baltic region (CEDEFOP, 2018a). Also is VET receiving less governmental attention than university education, which leads to lower reputation levels. This causes one of the main challenges of VET education in the analysed countries, the low participation rate and policy gaps (Blinov \& Esenina, 2019).

\subsection{Poland}

The Polish VET system is still one of the most underdeveloped VET systems in Europe (Polcyn \& Gawrysiak, 2019). The approach of modernizing the educational system since 1999 is characterized by decentralization, so local government institutions are managing the majority of public education (Hoftijzer et al., 2018a). But educational outcomes of VET students are unsatisfactory and cognitive skill levels of VET students in Poland are significantly lower than general education students (Burski et al., 2013).

In 2016 only $3.7 \%$ of the population aged 25 to 64 is participating in lifelong learning, representing a figure notable below the $10 \%$ EUROPE 2020 strategy target (CEDEFOP, 2017a). In Poland, the general requirement of a higher education degree does not apply for VET teachers. They require the title of master in a craft or a vocational qualification certificate and two years of experience (Hoftijzer et al., 2018a). At the same time the VET education is lasting 24 to 36 months and mostly imparted theoretically in basic vocational schools (OIC Poland Foundation, 2017). Still, the overall participation in VET in Poland is slightly rising from a low level.

Important education system reforms were undertaken in December 2016 with the purpose of establishing a VET system that fulfils the needs of a modern economy. Key elements are the extension of the vocational upper secondary programme from four to five years and the introduction of twostage sectoral programmes (Chłoń-Domińczak et al., 2019). Other reforms additionally addressed the improvement and provision of career guidance and the strengthening of collaboration between VET schools and employers. VET schools in Poland are now obligated to cooperate with employers when launching new programmes. They are also responsible for adjusting the curricula to reflect local needs in the course of the core curricula provided by the Ministry of National Education (OECD, 2019a). In the context of these reforms curricula were updated and modernized and a new 
core curricula was launched (Chłoń-Domińczak et al., 2019).

Serious challenges remain regarding the recruitment and development of VET teachers. $69 \%$ of Polish VET schools are having recruitment problems (Lis \& Miazga, 2014) and the VET teaching workforce is insufficiently engaged in professional development activities (OECD, 2019b). Since 2015, Poland's educational system for VET allows and encourages WBL by even offering a financial compensation for employers that make use of this system, but it is still hardly implemented (Hoftijzer et al., 2018b).

\subsection{Lithuania}

VET in Lithuania is still carrying the poor image of being a soviet times tool for the segregation of low performing students and for providing low value and outdated education (Laužackas et al., 2004). But Lithuania implemented basic dual learning and since then VET has developed significantly (Kumpikaite-Valiūniene et al., 2016). This started with the establishment of a competencebased education approach in VET 1995 (Tūtlys \& Aarna, 2017). In 2010 the national qualification framework was introduced and within the action plan for VET development 2014-16, the optimization and improvement of VET institutions, programs and teachers became a priority. Sectoral qualification standards were introduced, and VET programmes modularized (CEDEFOP, 2014). VET institutions in Lithuania are flexible and can adapt up to $20 \%$ of the programme due to their needs. Further, the promotion of apprenticeship-type schemes as an alternative to traditional schoolbased learning has increased recently with the introduction of apprenticeship contracts as a new type of employment contract in 2017, the followup amendments in the national Labour Code and the 2019 resolution. (Vaitkute et al., 2019; CEDEFOP, 2020).

Firms in Lithuania have limited capacities to interact and provide VET and are willing to commit to structured training. At the same time firms have high expectations and await ready and trained workers from school-based programs (OECD, 2018). The new apprenticeship contract creates a formal basis between VET providers and firms to organise the theoretical and practical parts of the given VET programme. The popularity of apprenticeship VET programmes rose and numbers of learners doubled in the period of 2014-2018, but still account for only 3\% of all VET learners. $40 \%$ of VET institutions already offer apprenticeship programmes and the new legislations objective is to increase the share of apprenticeship students to $20 \%$ of all VET graduates (CEDEFOP, 2020).

The institutional setting for VET teachers in Lithuania is very centralised and the role and requirements of a VET teacher defined by law. The Ministry of Education, Science and Sport organizes VET education, is responsible for the teachers training, and stated that all vocational teachers must have vocational qualifications. Currently, more detailed occupational standards for the qualifications of VET teachers are under development (Tūtlys et al., 2019). A shift of orientation towards a stronger focus on concrete competences already took place in Lithuania (Vaitkute et al., 2019), but as one of the key challenges remains the lack of attractiveness of the VET teacher career, chiefly caused by the low salaries. Most of the practicing VET teachers have LTQF/EQF level 4 qualification, but VET centres want to employ e.g. teachers with a LTQF/EQF level 6 qualification, which becomes due to low salaries very challenging (Tūtlys et al., 2019).

The need for further encouragement of participation in VET programmes among students remains another challenge. The participation rates in VET programmes in upper secondary education are with $26.7 \%$ of all students participating below the EU-28 average of $47.3 \%$. The low rate of $7.3 \%$ of the population participating in lifelong learning is intended to be increased by the Ministries of Education and Science, Social Security and Labour and Economy to $12 \%$ by 2022 (CEDEFOP, 2018b).

The development of VET in Lithuania receives additional support by the action plan for lifelong learning for 2017-2020. It aims at updating VET curricula and methods, developing VET institutions and the development of efficient conditions and incentives for lifelong learning (CEDEFOP, 2018b).

\subsection{Latvia}

Since 2009 the VET system in Latvia has passed through substantial reforms. A policy paper with the aim to increase the attractiveness of vocational education passed in 2009 and resulted in a European social fund project. The aims of this project are the development of sectoral qualifications and raising efficiency and quality of vocational education. This reform was based on cooperation between the State and social partners. Sectoral expert councils aligned VET education and curricula with the needs of the economy. Financial support for vocational students resulting in widely spread allow- 
ances and scholarships incentivised vocational education additionally (CEDEFOP, 2015).

The reforms led to a share of more than $70 \%$ of VET students participating in EQF level 4 vocational secondary education with equal shares of work-based and school-based learning (CEDEFOP, 2018c). The share of students in VET programmes in upper secondary education is with $39.6 \%$ close to the EU-28 average, but the participation rate of $5.7 \%$ in lifelong learning is still below the $15 \%$ target of the EUROPE 2020 strategy (CEDEFOP, 2017b).

Promoting more participation remains a main challenge of the VET system in Latvia and can be tackled with a further developed career guidance system, based on labour market needs and labour market outcomes of education (CEDEFOP, 2018c). The OECD recommends to encourage participation from low-income families with more generous grants and to strengthen work-based training (OECD, 2016).

Other studies are indicating that a stronger focus on extra-curriculum activities and a diversification of teaching and learning methods to promote more social, self-management and emotional competences (Līce, 2019a) and intentions to encourage each student to take responsibility about his personal growth and his ambitions (Kiris, 2019) are the right development path for the Latvian VET system. This is supported by other findings, indicating positive relationship between employability and the opportunity to develop planning and selforganising competencies in vocational education (Līce, 2019b). The majority of Latvian employers support the introduction of WBL in the Latvian VET system but does not feel fully prepared to do actually offer the training positions (Buligina et al., 2014).

Another main challenge is the state of the adult education system. Actions to increase employers' active cooperation with VET providers were introduced (CEDEFOP, 2018c). Additional support could be generated by lifting the VET providers limits on own earnings to make it more attractive for VET providers to offer adult education (OECD, 2019b).

\subsection{Russia}

Dual education in Russia received limited attention since the collapse of the Soviet system. This fundamentally changed at December 23th 2013, when Vladimir Putin declared the training of skilled workers and engineering personnel for the real economy a top priority (Administration of President of the Russian Federation Service, 2013).
Previous educational reforms resulted in budgets cuts for VET education, due to priority shifts towards primary education. The new efforts resulted in a strategic transformation of the Russian VET system in accordance to the German VET system supported by the launch of a project of the Agency for Strategic Initiatives in 2013. To this end a German-Russian group was created, to work on improving vocational education, which was still suffering from structural problems (Abankina et al., 2017).

The German-Russian VET initiative led to a focus on the implementation of a practice-oriented VET approach. Additional attention was drawn to employer engagement to increase collaboration between firms and Vet providers (Blinov \& Esenina, 2019). The formation of partner networks was encouraged, as well as the financial contribution of firms to VET education, to create production and educational clusters. More than 800 VET providers participated in creating these clusters and received funds and firm contributions to finance the modernization of the learning and teaching facilities (Abankina et al., 2017).

Simultaneously an initiative for updating the VET curricula was launched (Zolotov \& Oleynikova, 2014). This ensured the alignment of vocational students skills and firm needs. For the program's success the federal attention for VET education was crucial and a more important factor than the funding. Its close institutional monitoring and the confidence in the Russian-German partnership ensured firms commitment and contribution of resources and VET providers willingness to transform their curricula (Remington, 2017).

Challenges remain in the area of lifelong learning, which is yet not a recognized mission and idea by all educational institutions, businesses and the state. It requires more self-organization, innovation and competitiveness to be successfully integrated in the economy and educational system. Also more agility in updating VET education curricula and systems in regard of modern competencies and changing skill needs is necessary $(\mathrm{Ru}-$ sakova \& Saychenko, 2019).

\section{First results of survey and research methodology}

In a large-scale survey of all European Member States and Russia, companies, educational providers, business associations and public authorities will be asked about the status of WBL in their countries. The survey will run from January 2020 to the end of April 2020, so at the time of publica- 
tion of this article, the preliminary results will be analysed, not for all European countries, but only for those in the Baltic Sea region. There have already been 103 responses so far, so that initial conclusions can already be drawn. These are summarised below for the most important aspects.

This research is based on quantitative approach. The survey was distributed by a network of universities, business chambers and through the European Network NetWBL to gather results. The overall aim was to find out more about the interested of companies in WBL. The questionnaire exists of up to 15 questions and ratings and is structured in a piped-logic, i.e. companies that indicate they already train in the dual system receive different follow-up questions than companies that are not offering this training yet. The survey uses multiple choice questions, ratings and allows open statements, that, however, were hardly used. Reflecting the results, it should not be neglected, that companies finding the time to answer questions about dual education or WBL probably already have an interest in the topic while companies that are not interested at all are more likely to not answer any questions. Before the survey was send to the targeted stakeholders, it was tested and discussed with experienced professionals in the field of dual education.

\subsection{Companies already involved in WBL}

Those companies that already offer dual training and are thus involved in WBL measures come mainly from Denmark, Germany, Finland and Sweden in the Baltic Sea region. In Lithuania, only one out of 39 companies stated that they already provide WBL. Like Figure 1 shows, those companies that offer WBL have many years of experience in this area, the majority more than 20 years $(42.86 \%)$ or more than 10 years $(27.57 \%)$

The SMEs that already offer WBL were further asked whether they would recommend this system. As Figure 2 shows, the answer is clear and none of the practising companies seems to regret it.
$85.79 \%$ of the companies recommend WBL in any case, $14.21 \%$ under certain circumstances.

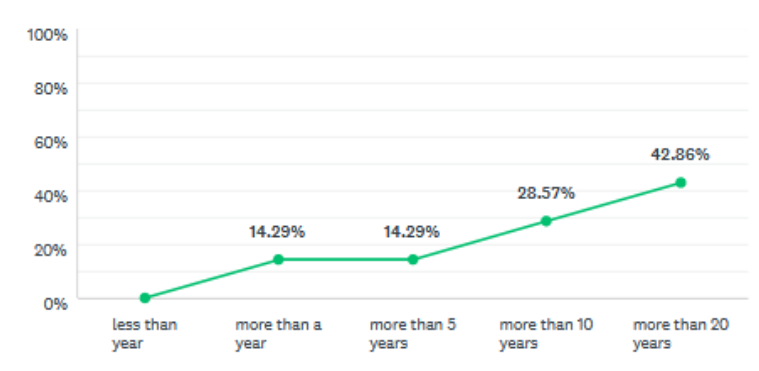

Figure 1. WBL Experience of companies

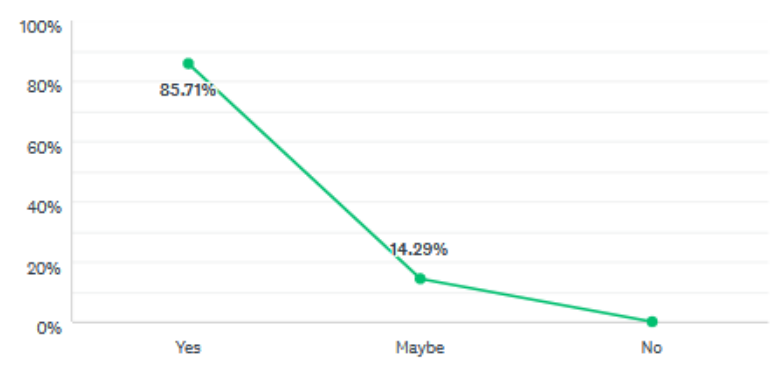

Figure 2. Recommendation of WBL

\subsection{Companies not involved in WBL}

Those companies that are not yet active in the WBL system were asked to state the reasons for this. It was shown very clearly that it is not a lack of interest from these companies, only $9 \%$ agreed, like Table 1 shows.

The decisive factor for most of them is rather a lack of qualified trainers $(52.38 \%$ fully agreed, $38.10 \%$ agreed). Recent studies confirm, that indeed qualified trainers are a prerequisite for a successful WBL system (Fuller \& Unwin, 2019) and many countries still lack competent trainers for WBL (Buligina \& Kaikkonen, 2018). Furthermore the assumption that national education law does not allow WBL (38.10\% fully agreed, $33.33 \%$ agreed) is seen as a hindrance - although this is no longer the case in most countries, as shown above.

Table 1. Reasons for companies not applying WBL

\begin{tabular}{|l|c|c|c|c|c|}
\hline & Fully agree & Agree & Agree somehow & Hardly agree & No, I disagree \\
\hline We/My company is not interested & $0.00 \%$ & $4.76 \%$ & $4.76 \%$ & $38.10 \%$ & $\mathbf{5 2 . 3 8 \%}$ \\
\hline $\begin{array}{l}\text { Trainees/Students spend too much time at } \\
\text { school/university }\end{array}$ & $14.29 \%$ & $71.43 \%$ & $8.52 \%$ & $4.76 \%$ & $0.00 \%$ \\
\hline We do not have qualified staff to supervise & $\mathbf{5 2 . 3 8 \%}$ & $38.10 \%$ & $9.52 \%$ & $0.00 \%$ & $0.00 \%$ \\
\hline We do not have enough information about WBL & $9.52 \%$ & $0.00 \%$ & $42.86 \%$ & $14.29 \%$ & $\mathbf{3 3 . 3 3 \%}$ \\
\hline We do not see the advantages of WBL & $0.00 \%$ & $14.29 \%$ & $4.76 \%$ & 28.57 & $\mathbf{5 2 . 3 8 \%}$ \\
\hline $\begin{array}{l}\text { Our national education law/educational system } \\
\text { does not allow this }\end{array}$ & $\mathbf{3 8 . 1 0 \%}$ & $33.33 \%$ & $23.81 \%$ & $0.00 \%$ & $4.76 \%$ \\
\hline
\end{tabular}


Table 2. Challenges of WBL

\begin{tabular}{|l|c|c|c|c|c|}
\hline & $\begin{array}{c}\text { No chal- } \\
\text { lenge at all }\end{array}$ & $\begin{array}{c}\text { No big chal- } \\
\text { lenge }\end{array}$ & Somehow & $\begin{array}{c}\text { Yes, pretty } \\
\text { challenging }\end{array}$ & $\begin{array}{c}\text { Yes, major } \\
\text { challenge }\end{array}$ \\
\hline $\begin{array}{l}\text { Finding companies that are willing to take } \\
\text { WBL students trainees }\end{array}$ & $15.52 \%$ & $25.86 \%$ & $15.52 \%$ & $15.52 \%$ & $27.59 \%$ \\
\hline $\begin{array}{l}\text { Creating corresponding curricula between } \\
\text { companies and schools/universities }\end{array}$ & $3.45 \%$ & $25.86 \%$ & $43.10 \%$ & $15.52 \%$ & $12.07 \%$ \\
\hline $\begin{array}{l}\text { Recognition of practical, non formal skills as } \\
\text { part of the formal training }\end{array}$ & $3.45 \%$ & $27.59 \%$ & $31.03 \%$ & $31.03 \%$ & $6.90 \%$ \\
\hline $\begin{array}{l}\text { Finding interested trainees, students that } \\
\text { would like to be qualified }\end{array}$ & $12.07 \%$ & $23.86 \%$ & $20.69 \%$ & $29.31 \%$ & $12.07 \%$ \\
\hline $\begin{array}{l}\text { Outdated matching curricula between practi- } \\
\text { cal skills and school education }\end{array}$ & $10.34 \%$ & $29.31 \%$ & $31.03 \%$ & $15.52 \%$ & $13.76 \%$ \\
\hline
\end{tabular}

Filtered only by 39 company responses from Lithuania, these also highlighted, that the major barrier for them not to get involved is legal possibility ( $42 \%$ fully agreed, $31 \%$ agreed). This is remarkable in that, as shown above, the Lithuanian education system has certainly created opportunities for WBL since the recent change in the law. However, it seems that this has not yet reached the private sector. This corresponds to another recent survey, done by the Kaunas Chamber of Commerce, where out of 89 Lithuanian companies, $70.8 \%$ reported that they are not aware of the new law on apprenticeships (TTT4WBL, 2020).

\subsection{Structuring of WBL}

There are many different approaches to the exact design of a WBL training. In particular with regard to the proportion of practical training in the company and theoretical training in school. This discussion has been taken up in the survey. When questioned in this respect, it was stated on average among all replies that the practical percentage should be $65 \%$. However, if one filters this result according to the answers of schools, they consider a practical share of $44 \%$ to be sufficient. Businesses would prefer a practical share of $74 \%$.

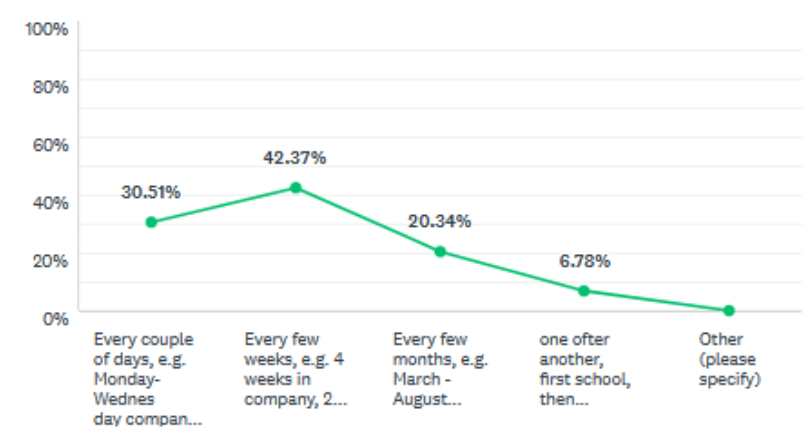

Figure 3. WBL Models

It was further collected to what extent there should be a shift between practical training in the company and teaching in school for the trainee/student, i.e. how many times during the week, month or semester the trainee should change between school and university.

With $42.37 \%$ most favoured a weekly change, i.e. several weeks of training on the job, in the company, followed by weeks in school or vice versa. $30.51 \%$ would even prefer a few days in the company, followed by a few days in the school. A monthly change was indicated as the best model by $20.34 \%$ while only $6.78 \%$ would prefer to do first the school training, than the company training. This last solution would not really be a WBL system, since there is no on-going connection between the two training capacities. It must be noted, that more than $72 \%$ are in favour of a close exchange between school and company training within days or weeks, which is a solid indicator for the need of WBL.

\subsection{Challenges of WBL}

The implementation of WBL is certainly associated with challenges. This is especially true for the first-time introduction, as has been the case in recent years in the new member states in the Baltic Sea region. The participants were asked, which are the most prominent challenges of the WBL system. Overall, however, the potential challenges were rated lower than expected. Identifying suitable companies that are willing to train in the WBL system was rated as a major obstacle with $27.59 \%$, as Table 2 demonstrates. However, it can be seen that the companies set a significantly lower value and the schools and business associations a higher one. A further difficulty in many countries seems to be the recognition of non-formal skills within the framework of WBL, which was rated as somewhat challenging by $31.32 \%$. The creation of consistent curricula was rated as only moderately challenging by $41 \%$. Outdated curricula or a lack of interested potential trainees / students are of little relevance. 
Table 3. Advantages of WBL

\begin{tabular}{|l|c|c|c|c|c|}
\hline & $\begin{array}{c}\text { No advantage } \\
\text { at all }\end{array}$ & Not really & $\begin{array}{c}\text { Somehow } \\
\text { true }\end{array}$ & Yes & $\begin{array}{c}\text { Yes, major } \\
\text { advantage }\end{array}$ \\
\hline $\begin{array}{l}\text { WBL helps students/trainees to connect to } \\
\text { potential employer }\end{array}$ & $0.00 \%$ & $0.00 \%$ & $22.81 \%$ & $40.35 \%$ & $36.84 \%$ \\
\hline WBL gives students opportunities to practise & $0.00 \%$ & $0.00 \%$ & $14.04 \%$ & $29.82 \%$ & $58.14 \%$ \\
\hline $\begin{array}{l}\text { "Learn and Earn" (trainees usually get salary } \\
\text { while being educated) }\end{array}$ & $5.26 \%$ & $14.04 \%$ & $42.11 \%$ & $28.07 \%$ & $10.53 \%$ \\
\hline $\begin{array}{l}\text { Communicational skills with co-workers and } \\
\text { customers }\end{array}$ & $0.00 \%$ & $3.51 \%$ & $24.56 \%$ & $35.09 \%$ & $36.84 \%$ \\
\hline $\begin{array}{l}\text { Develop essential employability skills thatare } \\
\text { nedded on the job }\end{array}$ & $0.00 \%$ & $1.75 \%$ & $12.28 \%$ & $42.11 \%$ & $43.86 \%$ \\
\hline $\begin{array}{l}\text { Companies are connected to educational curricu- } \\
\text { la, knowhow exchange }\end{array}$ & $1.75 \%$ & $8.77 \%$ & 26.32 & $35.09 \%$ & $28.07 \%$ \\
\hline
\end{tabular}

\subsection{Advantages of WBL}

Finally, the SMEs and institutions participating in the survey were asked about the benefits. Here the picture is essentially uniform and the assumed advantages are confirmed. With very few exceptions, all the assumptions made were considered to be at least true or better, as a major advantage, like Table 3 shows.

The advantage that trainees/students are already earning money in the dual system was rated the weakest, as they are usually paid a low salary for the time in the company (10.53\%). 63,16\% confirmed it a solid advantage, that by being part of the WBL system, companies are in constant exchange with educational providers and facilitate a knowhow exchange between theory and practise. The increased communicational skills with coworkers and customers due to the real working life conditions was indicated by $71.93 \%$ as more than only somehow true. That the WBL education support the connection between trainees/students and their later potential employer was rated by $77.19 \%$ as more than only somehow true. The trainees in the WBL environment develop essential skills that are in fact needed on that concrete job was confirmed by $85.79 \%$ as a clear advantage that is more than only somehow relevant. That WBL provides students with opportunities to practise was fully confirmed by $85.96 \%$ (including $56.14 \%$ considering it a major advantage, the highest overall number).

\section{Conclusions}

It was initially pointed out that the lack of skilled labour is a major issue for small and medium-sized enterprises in particular, in order to remain the innovative driving force for the economy in the Baltic Sea Region. Qualified specialists who meet the actual requirements of the labour market can best be trained with a strong involvement of the private sector, especially in the WBL system. While WBL has been firmly established in the old, northern and western countries of the Baltic Sea region for many decades, it is still in the trial phase for the newer EU member states and Russia. As has been shown by Poland, Latvia, Lithuania and Russia as examples, the necessary conditions have been created by the legislator in these countries in recent years. This is noteworthy in a current investigation, which most companies have apparently not yet taken full note of. The further, initial evaluation of this large-scale survey has shown that the private sector in particular is very interested in the WBL system and that the advantages clearly outweigh the challenges. It can be assumed that this demand from companies will be increasingly met and WBL systems will continue to spread.

\section{References}

Abankina, I., Dudyrev, F., \& Shabalin, A. (2017). Management of VET system: From budget dependency to public-private partnerships. Journal of the New Economic Association, 36(4), 174-181. https://doi.org/10.31737/2221-2264-2017-36-4-8

Administration of President of the Russian Federation Service. (2013). Protocol of the Joint meeting of the State Council and the Commission for monitoring the achievement of target indicators of socioeconomic development, 23.12.2013.

http://www.kremlin.ru/events/president/news/19882

Blinov, V., \& Esenina, E. (2019). Dual VET in Russia: Progress, problems and perspectives.TVET@Asia, $13,1-15$.

Buligina, I., \& Kaikkonen, L. (2018). Implications for training the trainers in work-based learning - the Baltic context. New challenges of economic and business development - 2018: Productivity and economic growth. Proceedings (pp. 97-105). Latvia University. http://urn.fi/URN:NBN:fi-fe202002145469 
Buligina, I., Putans, R., \& Sloka, B. (2014). Coherence of work based learning and regional development in Latvia. Economics and Business, 25, 19-26. https://doi.org/10.7250/eb.2014.003

Burski, J., Chłoń-Domińczak, A., Palczyńska, M., Rynko, M., \& Śpiewanowski, P. (2013). Umiejętności Polaków-wyniki Międzynarodowego badania kompetencji osób dorostych (PIAAC).

CEDEFOP. (2014). Lithuania - action plans for developing vocational education and training and nonformal adult education.

https://www.cedefop.europa.eu/fi/news-andpress/news/lithuania-action-plans-developingvocational-education-and-training-and-non

CEDEFOP. (2015). Vocational education and training in Latvia.

https://www.cedefop.europa.eu/en/publicationsand-resources/publications/4134

CEDEFOP. (2017a). Spotlight on VET Poland. https://www.cedefop.europa.eu/en/publicationsand-resources/publications/8125

CEDEFOP. (2017b). Spotlight on VET Latvia. https://www.cedefop.europa.eu/en/publicationsand-resources/publications/8107

CEDEFOP. (2018a). European cooperation in VET: one process, many stops. Developments in vocational education and training policy 2015-17. https://www.cedefop.europa.eu/en/publicationsand-resources/publications/3079

CEDEFOP. (2018b). Spotlight on VET Lithuania. https://www.cedefop.europa.eu/en/publicationsand-resources/publications/8121

CEDEFOP. (2018c). Vocational education and training in Europe: Latvia 2018. https://www.cedefop.europa.eu/de/publicationsand-resources/country-reports/vocationaleducation-and-training-europe-latvia-2018

CEDEFOP. (2020). Lithuania: New steps to implement apprenticeships in VET.

https://www.cedefop.europa.eu/en/news-andpress/news/lithuania-new-steps-implementapprenticeships-vet

Chłoń-Domińczak, A., Dębowski, H., ŻelażewskaHolzer, D., \& Maliszewska, A. (2019). Vocational education and training in Europe - Poland. Cedefop ReferNet VET in Europe reports 2018.

Dessinger, T. (2000). The German "philosophy" of linking academic and work-based learning in higher education: The case of the "vocational academies". Journal of Vocational Education \& Training, 52(4), 605-626. https://doi.org/10.1080/13636820000200134

European Commission. (2019). Annual report on European SMEs. Internal Market, Industry, Entrepreneurship and SMEs.

https://ec.europa.eu/growth/smes/businessfriendly-environment/performancereview_en\#annual-report
Fuller, A., \& Unwin, L. (2019). Improving workplace capacity as the prerequisite for effective workbased learning: A co-production approach. In A. Bahl, \& A. Dietzen (Eds.), Work-based learning as a pathway to competence-based education (Part II, pp. 69-84). https://discovery.ucl.ac.uk/id/eprint/10082527/

Hähn, K., Krone, S., \& Ratermann-Busse, M. (2016). Dual Studieren - und dann? IAQ-Report, 2016(1). https://doi.org/10.17185/duepublico/45735

Hoftijzer, M., Stronkowski, P., \& Rozenbaum, J. (2018a). Background: VET and WBL in Poland. The World Bank. https://doi.org/10.1596/978-1-4648-1322-1_ch2

Hoftijzer, M., Stronkowski, P., \& Rozenbaum, J. (2018b). Getting out of school and into the workplace: Strengthening work-based learning in upper secondary technical education in Poland's Swietokrzyskie region. The World Bank. https://doi.org/10.1596/978-1-4648-1322-1

Hogeforster, M. (2014). Future challenges for innovations in SMEs in the Baltic Sea Region. ProcediaSocial and Behavioral Sciences, 110(1), 241-250. https://doi.org/10.1016/j.sbspro.2013.12.867

Hogeforster, M. A., \& Priedulena, E. (2014). The significance and impact of innovation networks of academia and business with a special emphasis on work-based learning. Baltic Journal of European Studies, 4(2), 69-82. https://doi.org/10.2478/bjes-2014-0016

Kaikkonen, L., \& Maunonen-Eskelinen, I. (Eds.). (2020). Does the tandem approach work: Research on the experimentation testing the professional development model for tutors in work-based learning in the Baltic countries. In Jyväskylän ammattikorkeakoulun julkaisuja, Jyväskylän ammattikorkeakoulu.

Kiris, K. (2019). Excellence centers of education in Latvia. In $77^{\text {th }}$ Scientific Conference of University of Latvia (pp. 43-52). https://doi.org/10.22364/htqe.2019.04

Kumpikaite-Valiūniene, V., Rollnik-Sadowska, E., \& Glińska, E. (2016). Education and future work attitudes of students in Poland and Lithuania: a comparative analysis. In Society. Integration. Education. Proceedings of the International Scientific Conference (Vol. IV, pp. 345-354). https://doi.org/10.17770/sie2016vol4.1564

Laužackas, R., Danilevičius, E., \& Gurskienė, O. (2004). Profesinio rengimo reforma Lietuvoje: parametrai ir rezultatai. Monografija. Vytauto Didžiojo universiteto leidykla. https://hdl.handle.net/20.500.12259/55635

Līce, A., \& Sloka, B. (2019a). Performance of vocational education in Latvia in developing employability of graduates. In Society. Integration. Education. Proceedings of the International Scientific Conference (Vol. V, pp. 222-232). https://doi.org/10.17770/sie2019vol5.3975 
Līee, A., \& Sloka, B. (2019b). Promoting emotional intelligence in vocational education as a method to achieve employability of graduates. Regional Formation and Development Studies, 29(3), 98107. https://doi.org/10.15181/rfds.v29i3.2006

Lindberg, H. M. (2017). Skills shortages and skills mismatch in Sweden - The primary cause of youth unemployment? In Conference: Ratio Colloquium for Young Social Scientists. Stockholm, Sweden.

Lis, M., \& Miazga, A. (2014). Time for quality in vocational education. IBS Policy Paper, 03/04.

McGuinness, S., Pouliakas, K., \& Redmond, P. (2017). How useful is the concept of skills mismatch? http://hdl.handle.net/10419/170770

Michelsen, S., \& Stenström, M. L. (Eds.). (2018). Vocational education in the Nordic countries: The historical evolution ( $1^{\text {st }}$ ed.). Routledge. https://doi.org/10.4324/9781315411811

Nikolov, A., Nikolova, D., Ganev, P., \& Aleksiev, Y. (2018). Skills mismatches: An impediment to the competitiveness of EU businesses. Brussels: European Economic and Social Committee.

OECD. (2016). OECD reviews of labour market and social policies: Latvia 2016. OECD Publishing, Paris. https://doi.org/10.1787/9789264250505-en

OECD. (2018). OECD reviews of labour market and social policies: Lithuania. OECD Publishing, Paris. https://doi.org/10.1787/9789264189935-en

OECD. (2019a). OECD skills strategy Poland: Assessment and recommendations. OECD Skills Studies. OECD Publishing, Paris. https://doi.org/10.1787/b377fbcc-en

OECD. (2019b). Economic policy reforms 2019: Going for growth. OECD Publishing, Paris. https://doi.org/10.1787/aec5b059-en

OIC Poland Foundation. (2017). National Report on Apprenticeship in Poland, Erasmus + project Services for Apprenticeships (SERFA).

https://www.serfa-project.eu/sites/default/files/ upload/projet/poland_national_report.pdfcore

Polcyn, J., \& Gawrysiak, M. (2019). Analysis of the effectiveness of vocational education in terms of labour market demand in Poland. In Conference Proceedings Determinants of Regional Development (No. 1).

Priedulena, E., \& Hogeforster, M. (Eds.). (2017). Qualification and integration of young people by dual vocational training. BoD-Books on Demand.

Remington, T. F. (2017). Business-government cooperation in VET: A Russian experiment with dual education. Post-Soviet Affairs, 33(4), 313-333. https://doi.org/10.1080/1060586X.2017.1296730

Rusakova, T. B., \& Saychenko, O. A. (2019). Continuing Vocational Education in Russia: Challenges, Problems and Principles of Implementation. In International Scientific Conference "Far East Con" (ISCFEC 2018). Atlantis Press.

https://doi.org/10.2991/iscfec-18.2019.103

Succi, C., \& Canovi, M. (2019). Soft skills to enhance graduate employability: Comparing students and employers' perceptions. Studies in Higher Education, 1-14.

https://doi.org/10.1080/03075079.2019.1585420

TTT4WBL. (2020). Survey on interest in apprenticeship in Lithuania.

https://ttt4wbl-project.eu/2020/02/26/survey-oninterest-in-apprenticeship-in-lithuania/

Tūtlys, V., \& Aarna, O. (2017). Competence-based approach in the education reforms of Lithuania and Estonia. In M. Mulder (Ed.), Competence-based vocational and professional education. Bridging the worlds of work and education (pp. 381-406). Cham, Switzerland: Springer.

https://doi.org/10.1007/978-3-319-41713-4_18

Tūtlys, V., Gedvilienè, G., Saniter, A., Klein, I., Tacconi, G., \& Perrini, M. (2019). Development of teaching competences of VET teachers and trainers in Germany, Italy and Lithuania. In B. E. Stalder \& C. Nägele (Eds.), Trends in vocational education and training research, Vol. II. Proceedings of the European Conference on Educational Research (ECER), Vocational Education and Training Network (VETNET) (pp. 397-404).

https://doi.org/10.5281/zenodo.3371603

Vaitkute, L., Perini, M., \& Tacconi, G. (2019). Implications of competence/learning outcomes-based VET curriculum reforms for the vocational teachers and trainers in Italy and Lithuania. In B. E. Stalder \& C. Nägele (Eds.), Trends in vocational education and training research, Vol. II. Proceedings of the European Conference on Educational Research (ECER), Vocational Education and Training Network (VETNET) (pp. 405-413).

https://doi.org/10.5281/zenodo.3371607

Veugelers, R., Ferrando, A., Lekpek, S., \& Weiss, C. T. (2019). Young SMEs as a motor of Europe's innovation machine. Intereconomics, 54(6), 369377. https://doi.org/10.1007/s10272-019-0855-7

Zolotoreva, N., \& Oleynikova, O. (2014). Trends and challenges in vocational education in Russia. Edukacja ustawiczna dorostych, 2, 7-14. 